\title{
Autosomal univalents as a common meiotic feature in Jadera haematoloma (Herrich-Schaeffer, 1847) and Jadera sanguinolenta (Fabricius, 1775) (Heteroptera: Rhopalidae: Serinethinae)
}

\author{
María José BRessa ${ }^{1 *}$, Alba G. PAPeSCHI ${ }^{2}$, Liliana MOLA² and Marcelo L. LARRAMENDY ${ }^{1}$ \\ ${ }^{1}$ Laboratorio de Citogenética y Cátedra de Citología, Facultad de Ciencias Naturales y Museo, Universidad Nacional de La Plata, La \\ Plata, Argentina \\ ${ }^{2}$ Departamento de Ciencias Biológicas, Facultad de Ciencias Exactas y Naturales, Universidad de Buenos Aires, Buenos Aires,
} Argentina

\begin{abstract}
So far, available cytogenetic data on 24 species of Rhopalidae reveal a male diploid chromosome number of 13 , with a pair of $\mathrm{m}$ chromosomes and an X0/XX (male/female) sex chromosome determining system. As a rule Heteroptera have holokinetic chromosomes and a pre-reductional type of meiosis: the autosomal bivalents and the $\mathrm{m}$ pseudobivalent segregate reductionally at first meiotic division, while the X chromosome segregates equationally. In the present study, the meiotic chromosome behaviour was analyzed in males from different Argentinean populations of Jadera haematoloma and J. sanguinolenta. Our results corroborate the diploid chromosome number and general patterns of male meiosis previously reported by other authors in samples from Brazil and Texas (USA). Among bivalents, one is remarkably larger and may present one or two terminal chiasmata. Comparison of mean chiasma frequency between Jadera haematoloma (5.63) and J. sanguinolenta (5.14) revealed that differences are significant. In most individuals of both species the largest pair appears as univalents in a variable number of cells and shows a regular meiotic segregation. Autosomal univalents orientate axially at metaphase I (with their long axis parallel to the spindle axis) and segregate equationally at anaphase I. At metaphase II they associate end-to-end forming a pseudobivalent that segregates reductionally at anaphase II. An hypothesis is suggested to explain the appearance of the largest pair, either as a ring/rod bivalent or as univalents within the same individual, although an asynaptic or desynaptic origin of the univalents cannot be ascertained. The highly regular meiotic behaviour of this autosomal pair could ensure a high fertility of the individuals, and could be considered a selectively neutral condition or, at least, not detrimental.
\end{abstract}

\section{INTRODUCTION}

Members of the family Rhopalidae are frequently called scentless plant bugs. The taxon was first recognised as a higher group by Amyot and Serville in 1853 as the "Rhopalides" and later considered as a subfamily of the Coreidae, it is currently treated as a distinct family (Schaefer, 1964; Schuh \& Slater, 1995). So far, two subfamilies (Rhopalinae and Serinethinae) comprising 18 genera and 209 recognised species are distributed in all major faunal regions in both the Old and the New Worlds (Schuh \& Slater, 1995).

Within Rhopalidae, 24 species from 12 genera have been cytogenetically analyzed so far. Available data confirm that all species are characterised by the possession of a pair of $\mathrm{m}$ chromosomes, an X0/XX (male/female) sex determining system, and a constant male/female diploid number of $13(10+2 \mathrm{~m}+\mathrm{X} 0) / 14(10+2 \mathrm{~m}+\mathrm{XX})$ (Ueshima, 1979). Wilson (1905) introduced the term $m$ chromosomes to describe the smallest chromosome pair in Hemiptera which behaves differently from both the autosomes and the sex chromosomes during meiosis. The $\mathrm{m}$ chromosomes are usually unpaired during early meiotic prophase I, but at diakinesis they come close together. At metaphase I they are always associated end-to-end (touch-and-go pairing) forming a pseudobivalent which segregates reductionally at anaphase I. The $\mathrm{m}$ chromosomes segregate equationally at the second meiotic division, resembling the autosomal bivalents. As the rule for the order Heteroptera, the family is cytologically characterised by the possession of holokinetic chromosomes and a pre-reductional type of meiosis: while the autosomal bivalents and the $\mathrm{m}$ chromosomes segregate reductionally at anaphase I, the sex chromosomes are achiasmatic and segregate equationally.

Among the Serinethinae, morphologically characterised by the presence of functional scent glands in the adults as a neotenic condition, the genus Jadera, Stål, 1862, with 18 species described so far, is committed to tropical and subtropical areas in the Neartic and Neotropical regions, distributed from the Southern United States to central Argentina (Göllner-Scheiding, 1979, 1982; Schuh \& Slater, 1995). Available cytogenetic data on the genus Jadera is scarce. So far, specimens of $J$. haematoloma (Herrich-Schaeffer, 1847) from Texas (USA) and $J$. sanguinolenta (Fabricius, 1775) from Brazil have been described (Piza, 1946; Porter, 1917). Reported data demonstrated that both species shared the corresponding cytogenetic characteristics of the family, with males carrying $13(10+2 \mathrm{~m}+\mathrm{X} 0)$ chromosomes (Piza, 1946; Porter, 1917).

In the present study we analyzed the meiotic chromosome behaviour in males of $J$. haematoloma and $J$. sanguinolenta from different Argentinean localities. Although the results corroborate that both species are characterised by a diploid chromosome number of 13 elements, including 10 autosomes, a pair of $\mathrm{m}$ chromosomes

* Corresponding author. Laboratorio de Citogenética, Facultad de Ciencias Naturales Musea, UNLP, Calle 46 Nro. 1010,1900 La Plata, Argentina; fax: (+54) 221423 3340; e-mail: mjbressa@arnet.com.ar 
and an $\mathrm{X} 0 / \mathrm{XX}$ sex determining system, the typical presence of autosomal univalents in $J$. haematoloma and $J$. sanguinolenta is recorded as a new meiotic feature for these species.

\section{MATERIAL AND METHODS}

Specimens and localities. The material included in the present study comprises 11 adult males of Jadera haematoloma collected from the Natural Preserve Martín García Island (Buenos Aires Province, 9 specimens captured in November 1995 and 1996) and Gualeguaychú (Entre Ríos Province, 2 specimens captured in February 1997), and 32 adult males of Jadera sanguinolenta obtained from the Natural Preserve Martín García Island (Buenos Aires Province, 11 specimens captured in November 1995), Gualeguaychú (Entre Ríos Province, 11 specimens captured in February 1997) and Iguazú National Park (Misiones Province, 10 specimens captured in
April 2000), all from Argentina. Four specimens of Jadera sanguinolenta were not included in the meiotic analysis since only spermatids were found in testes (See Table 1).

Cytogenetic analysis. Immediately after capturing, all specimens were fixed in methanol:glacial acetic acid (3:1), and maintained at $4^{\circ} \mathrm{C}$ until dissection. Afterwards, gonads were dissected free and kept in $70 \%$ ethanol $\left(4^{\circ} \mathrm{C}\right)$. Slides were made by the squash technique in $2 \%$ iron propionic haematoxylin following conventional procedures.

When required, chromosome spreads were stained with 4'6diamidino-2-phenylindole (DAPI) (Vectashield mounting medium H1200; Vector Laboratories, Burlingame, CA, USA). Analysis of the slides was performed in an Olympus BX50 fluorescence microscope equipped with appropriated filter combination.

Statistical analysis. Three level nested analysis of variance was used for statistical comparisons of mean chiasma frequency.

TABLE 1. Mean chiasma frequency and percentage of cells with univalents at diakinesis-metaphase I in specimens of Jadera haematoloma and Jadera sanguinolenta from Buenos Aires (BsAs), Misiones (M) and Entre Ríos (ER) Provinces*

\begin{tabular}{|c|c|c|c|c|c|c|c|c|}
\hline \multirow[b]{2}{*}{ Procedence } & \multicolumn{4}{|c|}{ Jadera sanguinolenta } & \multicolumn{4}{|c|}{ Jadera haematoloma } \\
\hline & Individual & $\begin{array}{l}\text { Number } \\
\text { of cells }\end{array}$ & $\begin{array}{l}\text { Mean chiasma } \\
\text { frequency }\end{array}$ & $\begin{array}{c}\% \text { of cells } \\
\text { with univa- } \\
\text { lents }\end{array}$ & Individual & $\begin{array}{l}\text { Number } \\
\text { of cells }\end{array}$ & $\begin{array}{l}\text { Mean chiasma } \\
\text { frequency }\end{array}$ & $\begin{array}{c}\% \text { of cells } \\
\text { with univa- } \\
\text { lents }\end{array}$ \\
\hline Natural Reserve & MGI-1 & 74 & 4.23 & 72.97 & MGI-1 & 11 & 5.45 & 9.09 \\
\hline Martín García Island & MGI-2 & 80 & 4.75 & 61.25 & MGI-2 & 13 & 5.30 & 7.69 \\
\hline \multirow[t]{8}{*}{ (BsAs) } & MGI-3 & 33 & 5.54 & 33.33 & MGI-3 & 54 & 5.61 & 7.40 \\
\hline & MGI-4 & 10 & 4.90 & 30.00 & MGI-4 & 29 & 5.55 & 3.45 \\
\hline & MGI-5 & 14 & 4.93 & 21.43 & MGI-5 & 22 & 5.54 & 0.00 \\
\hline & MGI-6 & 97 & 5.70 & 5.15 & MGI-6 & 57 & 5.86 & 0.00 \\
\hline & MGI-7 & 67 & 6.03 & 4.48 & MGI-7 & 24 & 5.87 & 0.00 \\
\hline & MGI-8 & 19 & 5.79 & 0.00 & MGI-8 & 5 & 5.60 & nd \\
\hline & MGI-9 & 9 & 5.44 & nd & MGI-9 & 3 & 6.00 & nd \\
\hline & MGI-10 & 8 & 5.75 & nd & & & & \\
\hline \multirow[t]{9}{*}{ Gualeguaychú (ER) } & $\mathrm{G}-1$ & 20 & 4.80 & 55.00 & G-1 & 49 & 5.71 & 2.04 \\
\hline & G-2 & 56 & 4.64 & 48.21 & G-2 & 4 & 5.50 & nd \\
\hline & G-3 & 11 & 4.73 & 45.45 & & & & \\
\hline & $\mathrm{G}-4$ & 19 & 5.37 & 21.00 & & & & \\
\hline & G-5 & 10 & 5.60 & 20.00 & & & & \\
\hline & G-6 & 11 & 5.18 & 18.18 & & & & \\
\hline & $\mathrm{G}-7$ & 75 & 5.69 & 0.00 & & & & \\
\hline & G-8 & 7 & 4.43 & nd & & & & \\
\hline & G-9 & 4 & 5.25 & nd & & & & \\
\hline Iguazú National Park & INP-1 & 33 & 4.73 & 57.57 & & & & \\
\hline \multirow[t]{8}{*}{ (M) } & INP-2 & 13 & 4.61 & 46.15 & & & & \\
\hline & INP-3 & 48 & 4.75 & 41.66 & & & & \\
\hline & INP-4 & 35 & 5.34 & 31.43 & & & & \\
\hline & INP-5 & 59 & 5.71 & 16.95 & & & & \\
\hline & INP-6 & 43 & 5.23 & 16.28 & & & & \\
\hline & INP-7 & 40 & 5.10 & 15.00 & & & & \\
\hline & INP-8 & 32 & 5.19 & 6.25 & & & & \\
\hline & INP-9 & 9 & 4.66 & nd & & & & \\
\hline
\end{tabular}

nd, frequency of cells with univalents not determined because of the reduced number of cells analyzed

*, data from four specimes of Jadera sanguinolenta are not included since only spermatids were found 
The level of significance chosen was 0.05 , unless indicated otherwise.

\section{RESULTS}

Jadera haematoloma and $J$. sanguinolenta possess a male diploid chromosome number of $13(10+2 \mathrm{~m}+\mathrm{X} 0)$ with an autosomal pair which is easily identified because of its large size. The $\mathrm{m}$ chromosomes are the smallest elements of the complement and the X chromosome is also of small size (Fig. 1a). From leptotene-zygotene to the diffuse stage the $\mathrm{X}$ chromosome is positively heteropycnotic and lies at the periphery of the nucleus (Fig. 1b-c). At zygotene and pachytene, chromosomes are too entangled to be clearly individualised. At pachytene, the autosomal bivalents can show a bouquet arrangement, and the $\mathrm{m}$ univalents and the $\mathrm{X}$ chromosome are recognised (Fig. 1b). Pachytene is followed by a diffuse stage. During this stage autosomal bivalents decondense completely, while the $\mathrm{X}$ chromosome and less frequently the $\mathrm{m}$ chromosomes remain positively heteropycnotic, at which time they are clearly identified (Fig. 1c). During diplotene, the $\mathrm{m}$ chromosomes continue separated, and from late diplotene onwards the $\mathrm{m}$ chromosomes are negatively heteropycnotic. During diakinesis the $\mathrm{m}$ chromosomes come close together and associate end-to-end to form a pseudobivalent (Figs 1d, 2a-b). At metaphase I, the m pseudobivalent lies in the centre of the ring formed by autosomal bivalents and the $X$ chromosome (Figs 1e-f, 1i, 2c). At anaphase I autosomal bivalents, as well as the $\mathrm{m}$ pseudobivalent, divide reductionally, while the sex chromosome divides equationally. Second metaphase follows immediately after telophase I, without an intervening interkinesis stage. At metaphase II the autosomes dispose at the equatorial plane, forming a ring, and the $\mathrm{X}$ chromosome always lies outside it. The $\mathrm{m}$ chromosome does not show any defined position and can be found either integrating with the ring (Fig. 1g) or inside it (Figs 1j, 2d). At anaphase II the $\mathrm{X}$ chromosome migrates precociously towards one pole (Fig. 2e) and decondenses later at telophase II (Fig. 2f).

In most individuals the $\mathrm{X}$ univalent is smaller than the smallest bivalent (Figs 1e, 1h, 2a). In both species the $X$ chromosome shows intraspecific size polymorphism. In one specimen of $J$. haematoloma from Martín García Island (MGI-4, Table 1) and in three specimens of $J$. sanguinolenta (MGI-8, MGI-9 and G-7, Table 1), the sex univalent is larger and similar in size to the smallest auto-

TABLE 2. Analysis of variance of mean chiasma frequency at diakinesis-metaphase I in specimens of Jadera haematoloma and Jadera sanguinolenta from Buenos Aires (BsAs), Misiones (M) and Entre Ríos (ER) Provinces

\begin{tabular}{|c|c|c|c|c|c|}
\hline & $\mathrm{df}$ & MS & $\mathrm{F}$ & $P$ & $\begin{array}{l}\text { VC } \\
(\%)\end{array}$ \\
\hline Between species & 1 & 39.00093 & 14.0742 & 0.0331 & - \\
\hline $\begin{array}{l}\text { Between populations } \\
\text { within species }\end{array}$ & 3 & 2.77109 & 0.4332 & 0.7306 & 0 \\
\hline $\begin{array}{l}\text { Between individuals } \\
\text { within populations }\end{array}$ & 34 & 6.39746 & 13.8787 & $4.333 \times 10^{-64}$ & 31.7 \\
\hline Error & 1,139 & 0.46095 & & & 68.3 \\
\hline
\end{tabular}

somal bivalent, but not readily identified at diakinesis and metaphase I (Figs 1f, 2b-c).

Autosomal bivalents generally present one terminal chiasma, although the largest bivalent and, less frequently, other bivalents, show two chiasmata (Figs 1d-f, 1h, 2a). Cells with two ring bivalents are seldom observed (Figs $1 \mathrm{~d}, 1 \mathrm{~h}, 2 \mathrm{a}$ ), while those with three or four ring bivalents are even more rare. Mean chiasma frequency in cells at diakinesis-metaphase I varies from 5.30 to 6.00 and from 4.23 to 6.03 in $J$. haematoloma and $J$. sanguinolenta, respectively (Table 1 ). The association between $m$ chromosomes at diakinesis-metaphase $\mathrm{I}$ is not considered as a real chiasma during the scoring process. ANOVA analysis revealed the existence of significant differences between the mean chiasma frequency of Jadera haematoloma (mean $\pm \mathrm{SD}=5.63 \pm 0.21)$ and $J$. sanguinolenta (mean $\pm \mathrm{SD}=5.14 \pm 0.46)(\mathrm{P}=0.03)$. In addition, a great variation was found among cells within individuals $(\mathrm{VC}=$ $68.3 \%$ ), as well as among individuals within populations $(\mathrm{VC}=31.7 \%$ ) (Table 2).

DAPI staining gave similar results for both species. At early prophase $\mathrm{I}$, the $\mathrm{X}$ and the $\mathrm{m}$ chromosomes were DAPI bright. At diakinesis all chromosomes stained homogeneously. At metaphase I, the $\mathrm{m}$ pseudobivalent was dull. No DAPI bright bands were observed in the autosomes at diakinesis-metaphase I.

A different frequency of cells with one pair of univalents was observed in $J$. haematoloma and $J$. sanguinolenta (Fig. 1h-i). The percentage of cells with univalents was five-fold higher in $J$. sanguinolenta (mean $\pm \mathrm{SD}=$ $16.27 \pm 1.55$, range $4.48-72.97$ ) than in $J$. haematoloma (mean $\pm \mathrm{SD}=3.09 \pm 0.68$, range 2.04-9.09) (Table 1) and, in most cases, univalents were derived from the largest autosomal pair (100\% and $94.7 \%$ of the cells, respectively). Among the 11 males of $J$. haematoloma analyzed, regular meiosis was only observed in three specimens $(27.3 \%)$, a pair of univalents was found in five specimens $(45.4 \%)$, while in the remaining three individuals $(27.3 \%)$ the presence/absence of univalents was not determined because there were few cells suitable for meiotic analyses (Table 1). Of the 32 males of $J$. sanguinolenta studied only two had a regular meiosis $(6.3 \%)$, while 21 individuals presented a variable percentage of cells with a pair of univalents $(65.6 \%)$. Moreover, the presence of four univalents was found in only two cells from two different individuals (Table 1). In the remaining nine specimens, the presence of univalents was not determined due either to the reduced number of cells analyzed $(15.6 \%)$ or the absence of meiotic activity in testes $(12.5 \%)$ (Table 1).

The specimens, independent of their origin, can be grouped into three different categories according to the percentage of univalents: low (all eight specimens from Jadera haematoloma, range $0.00-9.09$, and five specimens from Jadera sanguinolenta, 0.00-6.25), medium (10 specimens from $J$ sanguinolenta, range 15.00-33.33) and high (eight specimens from $J$. sanguinolenta, range 41.66-72.97) (Fig. 3). 


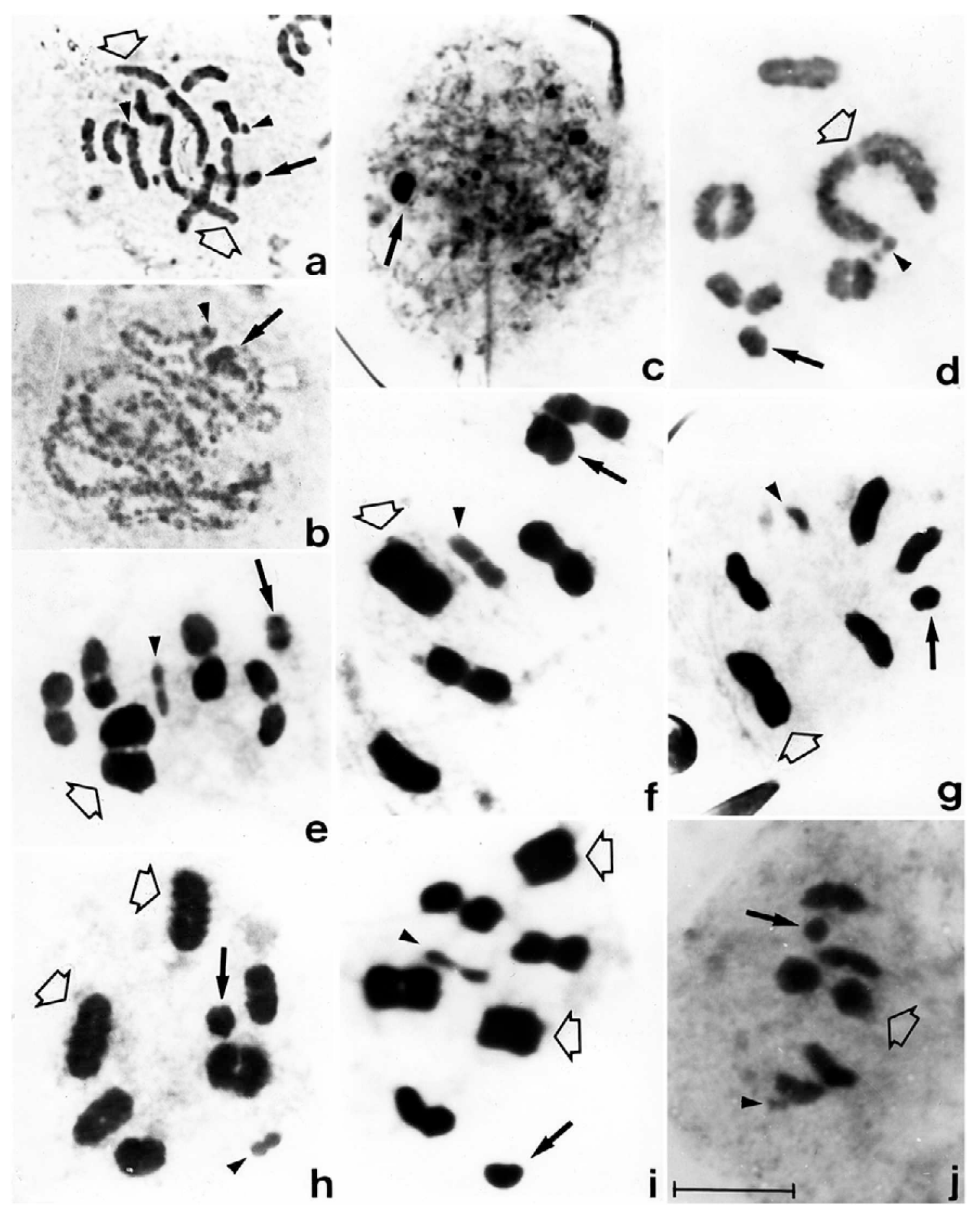

Fig. 1. Jadera sanguinolenta (Fabricius, 1775). a - mitotic prometaphase; $\mathrm{b}$ - pachytene; $\mathrm{c}$ - diffuse stage; $\mathrm{d}$ - diakinesis with two ring autosomal bivalents; e - metaphase I with the largest bivalent with two chiasmata and a small sized X chromosome; $\mathrm{f}-$ metaphase I with the largest bivalent with two chiasmata and a large sized X chromosome; $g$ - metaphase II; $h$ - diakinesis with the largest pair of autosomes as univalents; $i$ - metaphase I with the biggest pair of autosomes as univalents; $j-$ metaphase II with a pair of univalents associated in a pseudobivalent. Solid arrows indicate sex chromosome; solid arrowheads indicate $\mathrm{m}$ chromosomes; open arrows indicate largest autosomal pair. Bar represents $10 \mu \mathrm{m}$.

The analysis of the meiotic behaviour of univalents was performed in those individuals of $J$. sanguinolenta with a high frequency of univalency (MGI-1, MGI-2 and MGI-3). Autosomal univalents were detected from diplo- tene onwards. At metaphase I they lied at the equatorial plate forming part of the ring of autosomal bivalents, and orientated with their long axis parallel to the spindle axis (axial orientation) (Fig. 1i). At anaphase I, autosomal uni- 


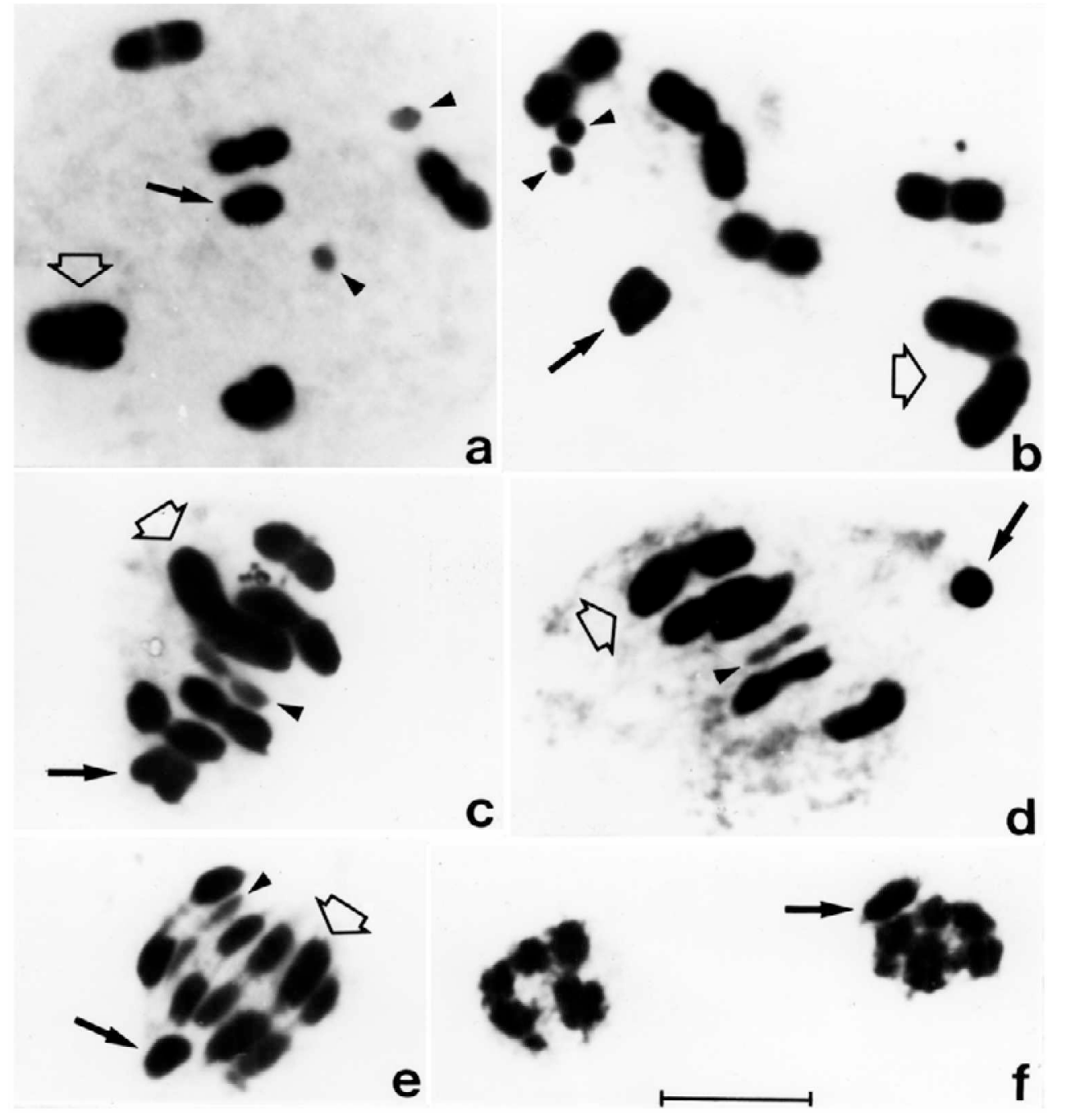

Fig. 2. Jadera haematoloma (Herrich-Schaeffer, 1847). a - diakinesis with the largest bivalent with two chiasmata and a small sized X chromosome; $\mathrm{b}$ - diakinesis with a large sized X chromosome; $\mathrm{c}$ - metaphase I with a large sized X chromosome; $\mathrm{d}$ - metaphase II; e - anaphase II; $\mathrm{f}$ - telophase II. Solid arrows indicate sex chromosome; solid arrowheads indicate m chromosomes; open arrows indicate largest autosomal pair. Bar represents $10 \mu \mathrm{m}$.

valents segregated equationally and migrated synchronously with the autosomes. At metaphase II single chromatids associated end-to-end (touch-and-go pairing), forming a pseudobivalent (Fig. $1 \mathrm{j}$ ), except in $6 \%$ of the cells (four out of 65), in which they remained separated. At anaphase II no laggards were observed. Although all telophase II nuclei analyzed showed $5 \mathrm{~A}+\mathrm{m}+\mathrm{X}$ or $5 \mathrm{~A}+$ $\mathrm{m}$, it cannot be discounted that a low percentage of cells (approximately $3 \%$ ) could be aneuploid.

\section{DISCUSSION}

More than 50 years ago, the diploid chromosome number $(2 \mathrm{n}=10+2 \mathrm{~m}+\mathrm{X} 0)$ of Jadera haematoloma from Texas (USA), as well as Jadera sanguinolenta from Brazil, were described (Piza, 1946; Porter, 1917). The results presented herein with specimens belonging to both spe- cies from different Argentinean localities are in accordance with the original scarce cytogenetic findings.

In their original descriptions, neither Porter (1917) (for $J$. haematoloma) nor Piza (1946) (for J. sanguinolenta) reported the number of individuals analyzed or identified their origin. Furthermore, they did not mention the presence of ring bivalents at diakinesis-metaphase I. Nevertheless, the presence of two chiasmata in some pairs of autosomes can be seen in the original figures (Piza, 1946; Porter, 1917). Our study clearly reveals the presence of up to four ring-shaped bivalents with two clear terminal chiasmata, and that the largest pair of autosomes is more prone to adopt this configuration. It is generally accepted that most Heteroptera possess, as a rule, only one chiasma per bivalent (Manna, 1984; Ueshima, 1979). However, our present observations in Jadera and previous findings in other heteropteran species, such as Largus rufipennis 


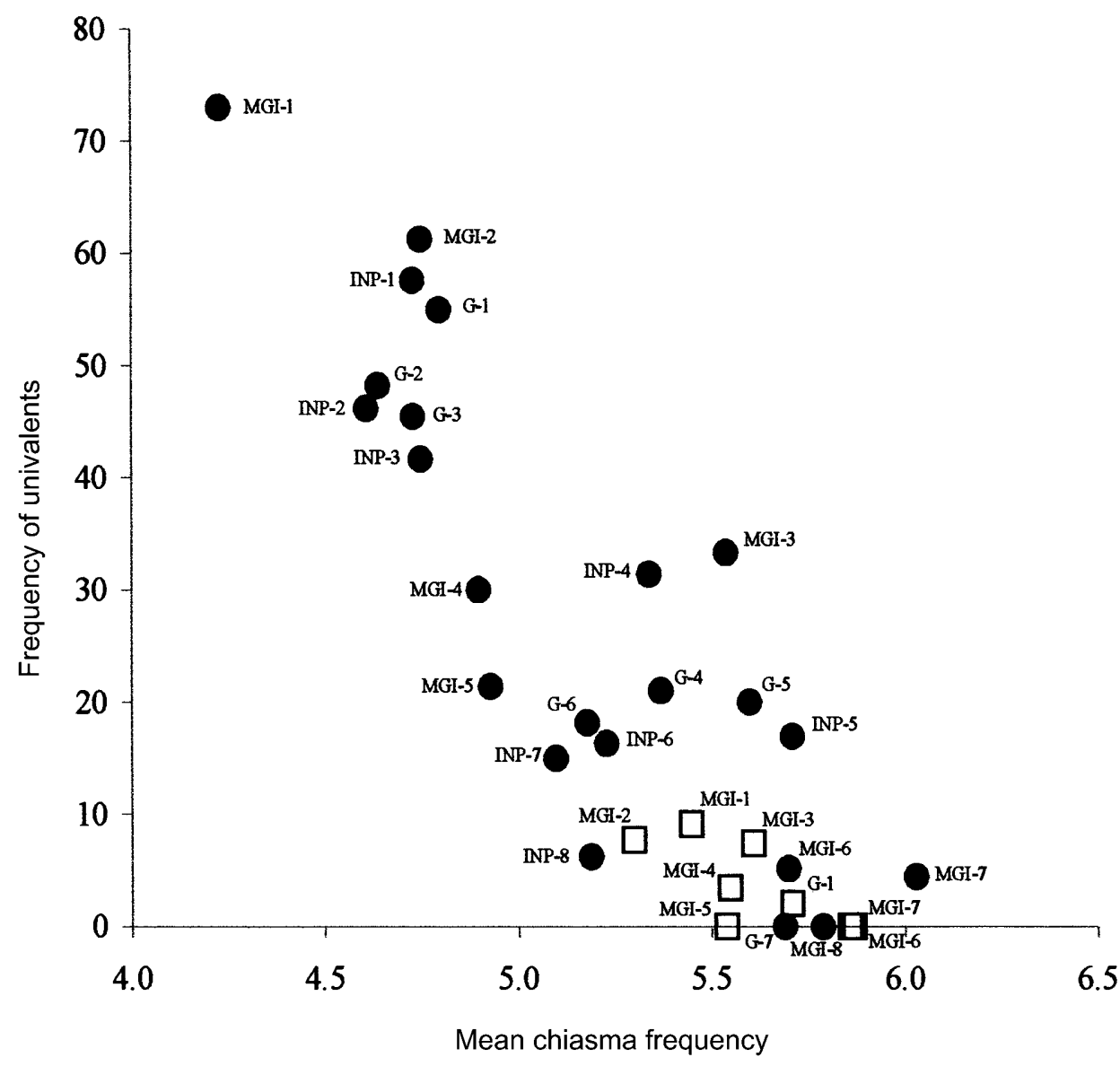

Fig. 3. Mean chiasma frequency in diakinesis-metaphase I plotted against percentage of cells with univalents in the specimens of Jadera haematoloma (empty squares) and Jadera sanguinolenta (solid circles) from Martín García Island (MGI), Gualeguaychú (G) and Iguazú National Park (INP) populations. Number after the locality code denotes specimen number from Table 1.

(Largidae) (Bressa et al., 1998; Mola \& Papeschi, 1993), Dysdercus albofasciatus (Pyrrhocoridae) (Bressa et al., 1999), Nezara viridula (Pentatomidae) (Camacho et al., 1985), among others, indicate that the frequency of ringshaped bivalents should be much higher than originally suggested.

One chromosomal feature observed in the specimens we analyzed is the presence of a size polymorphism of the $\mathrm{X}$ chromosome in both species. There are two possible explanations for the origin of this polymorphism; namely, fragmentation of an ancestral large $X$ element or addition of heterochromatin in a primitive small $\mathrm{X}$ chromosome. Due to the holokinetic nature of heteropteran chromosomes, fragments should persist leading to an increase in the chromosome number (Hughes-Schrader \& Schrader, 1961; Ueshima, 1979). Fragmentation of the X chromosome would then give rise to a multiple sex chromosome determining system, that so far has not been reported in Jadera. Accordingly, this hypothesis may be ruled out. Notwithstanding, because a homogeneous DAPI banding pattern of the $\mathrm{X}$ chromosome was found in both species, variations in its size are most probably attributable to addition of A-T rich heterochromatin during evolution.

It is generally accepted that univalent formation within a species may result from several causes, genotypic and environmental, even though the exact mechanism $/ \mathrm{s}$ for its formation is not always known. The individuals of $J$. haematoloma and $J$. sanguinolenta which we analyzed are characterised by the presence of a pair of univalents in a variable frequency, and the largest autosomal pair is most prone to be involved in its formation. All individuals from each population sample of both species were collected simultaneously, between late spring to late summer, within a six year period. Should an increase in the frequency of univalents be associated with a particular environmental condition of a single year or season, univalents should not have appeared in all distantly located populations from both species. Thus, an external environmental agent could then be ruled out as a possible inducing factor for univalency.

The presence of autosomal univalents could be due to a failure in the primary formation of the synaptonemal complex at zygotene (asynapsis) or to a failure in chiasma 
formation following normal synapsis (desynapsis). The synaptonemal complex formation is initiated at multiple sites, but within them there are primary and secondary centres of synapsis. The primary synapsis begins at the telomeric regions, congregated in one area of the nucleus (Appels et al., 1998). In the specimens from both species of Jadera analyzed, univalency involved almost always the same chromosome pair, but the origin of univalents can not be ascertained because of the characteristics of early prophase stages. This pair can be observed, within the same individual, as a bivalent with terminal chiasmata (either ring or rod shaped) or as univalents. We suggest that if one telomeric region of this autosomal pair (A) was altered in such a way that i) the pairing efficiency is reduced (partial asynapsis) or ii) pairing is delayed, restraining the occurrence of cross-overs, its chiasma frequency would be diminished. If the unique chiasma of the rod bivalent can be placed at random at both telomeric ends of the bivalents ( $\mathrm{A}$ or B), the alteration of the A telomeric region would result in the appearance, in some cells, of a pair of univalents. Moreover, the expected frequency of ring bivalents would also be lower because, in some cells, only one cross-over would take place (that of the $\mathrm{B}$ telomeric region).

When analyzing the behaviour of univalents, the observations described in the present report for both $J$. haematoloma and $J$. sanguinolenta agree well with previous observations in desynaptic specimens from other Argentinean heteropterans, such as Acanonicus hahni (Coreidae) and Largus rufipennis (Largidae) (Papeschi \& Mola, 1990; Mola \& Papeschi, 1993). Accordingly, these authors suggested that the behaviour possessed by such univalents (equational division at anaphase I and touchand-go pairing at metaphase II) is a characteristic condition of the univalent state in normal chiasmatic meiosis, regardless of whether the univalency affects autosomes or sex chromosomes, because it resembles the behaviour of the sex chromosomes in $\mathrm{XY}, \mathrm{X}_{\mathrm{n}} \mathrm{Y}$ and/or $\mathrm{XY} \mathrm{H}_{\mathrm{n}}$ sex determining systems commonly found in Heteroptera (Ueshima, 1979). An exception to this behaviour is the reductional segregation of autosomal univalents at first meiotic division in Calocoris quadripunctatus (Miridae), a species with achiasmatic meiosis of the collochore type (Nokkala, 1986).

The terminal position of chiasmata in the largest bivalent results in a large group of co-adapted genes. Equivalent genetic results are obtained when this pair is present as univalents. Furthermore, the highly regular behaviour of univalents in both $J$. haematoloma and $J$. sanguinolenta could ensure a high fertility of the individuals. The aforementioned characteristics suggest that the absence of chiasmata in this autosomal pair could be considered as a selectively neutral condition or, at least, not detrimental.

ACKNOWLEDGEMENTS. This study was supported by the National Agency of Scientific and Technological Promotion (Contract grant number: BID 802/OC-AR PICT No. 01-0000000754), the National Council of Scientific and Technological Research (CONICET), the National University of La Plata, and the National University of Buenos Aires (Grant number: TW01) from Argentina. The authors wish to thank Lic. Beatriz González for her advice in statistical analysis, Dr. Axel Bachmann and Lic. María Marta Schang for taxonomic identification of the specimens included in the study, and to the National Parks Administration from Argentina. The authors greatfully acknowledge the valuable suggestions made by the reviewers.

\section{REFERENCES}

Appels R., Morris R., Gill B.S. \& MaY C.E. 1998: Chromosome Biology. Kluwer Academic Publishers, Boston (Dorbrecht), London, XV+401 pp.

Bressa M.J., Papeschi A.G., Mola L.M. \& Larramendy M.L. 1998: Meiotic studies in Largus rufipennis (Castelnau) (Largidae, Heteroptera). II. Reciprocal translocation heterozygosity. Caryologia 51: 253-264.

Bressa M.J., Papeschi A.G., Mola L.M. \& Larramendy M.L. 1999: Meiotic studies in Dysdercus Guérin Méneville 1831 (Hereroptera: Pyrrhocoridae). I. Neo-XY in Dysdercus albofasciatus Berg 1878, a new sex chromosome determining system in Heteroptera. Chromosome Res. 7: 503-508.

Camacho J.P.M., Belda J. \& Cabrero J. 1985: Meiotic behaviour of the holocentric chromosomes of Nezara viridula (Insecta, Heteroptera) analyzed by C-banding and silver impregnation. Can. J. Genet. 27: 490-497.

GöllNER-SCHeming U. 1979: Die Gattung Jadera Stål 1862 (Heteroptera, Rhopalidae). Dtsch. Entomol. Z. 26: 47-75.

GöllnER-SCHELDING U. 1982: Erganzungen zu Gattungen der Rhopalidae. Dtsch. Entomol. Z. 29: 459-467.

Hughes-Schrader S. \& Schrader F. 1961: The kinetochore of the Hemiptera. Chromosoma 12: 327-350.

MANNA G.K. 1984: Chromosomes in evolution in Heteroptera. In Sharma A.K. \& Sharma A. (ed.): Chromosomes in Evolution in Eukaryotic Groups. CRC Press, Boca Ratton, pp 189-225.

Mola L.M. \& PAPESCH A.G. 1993: Meiotic studies in Largus rufipennis (Castelneau) (Largidae, Heteroptera). Frequency and behaviour of ring bivalents, univalents and B chromosomes. Heredity 71: 33-40.

NokKala S. 1986: The mechanisms behind the regular segregation of autosomal univalents in Calocoris quadripunctatus (Vil.) (Miridae, Hemiptera). Hereditas 105: 199-204

Papeschi A.G. \& Mola L.M. 1990: Meiotic studies in Acanonicus hahni (Stål) (Coreidae, Heteroptera). I. Behaviour of univalents in desynaptic individuals. Genetica 80: 31-38.

PIZA S.D.T. 1946: Aspectos interessantes observados na meiose de alguns Hemípteros. Anais de E. S. A. "Luiz de Queiroz" 3 : 347-362.

PORTER L.T. 1917: The spermatocytic divisions of Leptocoris haematoloma. Biol. Bull. 33: 316-320.

SChaefer C.W. 1964: The morphology and higher classsification of the Coreoidea (Hemiptera-Heteroptera): parts I and II. Ann. Entomol. Soc. Amer. 57: 670-684.

Schum R.T. \& Slater J.A. 1995: True Bugs of the World (Hemiptera: Heteroptera). Classification and Natural History. Cornell University Press, Ithaca, XII $+336 \mathrm{pp}$.

Ueshima N. 1979: Hemiptera II: Heteroptera. Gebrüder Borntraeger, Berlin-Stuttgart, $\mathrm{V}+17 \mathrm{pp}$.

WILSON E.B. 1905: Studies of chromosomes II. The paired microchromosomes, idiochromosomes and heterotropic chromosomes in Hemiptera. J. Exp. Zool. 2: 507-545.

Received September 5, 2000; revised January 30, 2001; accepted May 9, 2001, Editor: F. Marec 